\title{
Communication
}

\section{Activity of glycogen depolymerizing enzymes in extracts from brain tumor tissue (anaplastic astrocytoma and glioblastoma multiforme)}

Bogusław Kotoński ${ }^{1}$, Joanna Wilczek ${ }^{1}$, Janusz Madej ${ }^{2}$, Andrzej Zarzycki ${ }^{3}$ and Jan Hutny ${ }^{1 凶}$

${ }^{1}$ Department of Biochemistry and ${ }^{2}$ Department of Pathological Anatomy, Agricultural University of Wroclaw, Poland; ${ }^{3}$ Department of Neurosurgery, Medical Academy, Wroctaw, Poland

Received: 18 July, 2001; revised: 22 October, 2001; accepted: 19 November, 2001

Key words: $\alpha$-glucosidase, $\alpha$-amylase, phosphorylase, astrocytoma, glioblastoma

An approximately threefold increase in glycogenolytic activity of the neutral $\alpha$-1,4-glucosidase and a twofold increase in the same activity of the acid isoform have been found in extracts of anaplastic astrocytoma and glioblastoma multiforme tumors of brain tissue. "Maltase activity" of the respective enzymes increased by $60-80 \%$ in both kinds of tumor extracts. However a significant decrease in $\alpha$-amylase and almost complete disappearance of phosphorylase activities have also been found in both kinds of tumors.

Glial tumors (or "astrocytoma”) are classified into four types according to the degree of malignancy, type I being the slowest-growing one. This communication presents some aspects of glycogen metabolism studied in the type III anaplastic astrocytoma and in the highest malignancy glioblastoma multiforme (type IV).

It has been generally recognized that normal astrocytes help in the development and nour- ishing of neurons. There are also data showing participation of those cells in the process of neurotransmission [1]. Astrocytes are able to build up the glycogen store, which is supposed to be the energy reserve for the central nervous system [2,3]. Glycogen particles have also been found in glioma tumor cells [4], thus glycogen bound glucose molecules, as well as blood glucose, should serve as a substrate for glycolysis in both, normal astrocytes and tu-

\footnotetext{
${ }^{\square}$ Address for correspondence: Jan Hutny, Department of Biochemistry, Agricultural University of Wroclaw, C. Norwida 31, 50-375 Wroclaw, Poland; phone: (48 71) 320 5435; fax: (48 71) 321 1567; e-mail: hutny@star.ar.wroc.pl

Abbreviation: $\mathrm{NaCl} / \mathrm{P}_{\mathrm{i}}$, phosphate-buffered saline.
} 
mor cells. Metabolic flux through the lactate pool in rat $\mathrm{C} 6$ glioma tissue has been found to be 10-fold higher than through the glutamate pool [5]. This may suggest that nonoxidative glycolysis is used in brain tumors as a major source of ATP, and the Crabtree effect takes place there like in other tumor cells [6].

Glycogen phosphorylase, being the main enzyme responsible for glycogen breakdown, fulfills the same function in normal astrocytes as in other glycogen storing cells, but in glial tumor cells the phosphorolytic activity disappears almost completely [7]. Is it thus possible that blood glucose in those cells is the only substrate for glycolysis? Existence of glycogen particles in tumor cells seems incompatible with such a possibility and from this data arises the question on the likelihood of engagement, or the degree of potential engagement, of glycogen hydrolysing enzymes. Such enzymes, together with hexokinase, could replace the activity of phosphorylase in the transformation of glycogen into hexose phosphate esters.

In animal tissues the hydrolytic breakdown of glycogen is catalyzed mostly by the enzymes of the $\alpha$-glucosidase group [8] and in some tissues by $\alpha$-amylase [9]. The $\alpha$-glucosidase (EC 3.2.1.20) is responsible for the hydrolysis of $\alpha$-1,4-bonds from nonreducing ends of glycogen molecules, resulting in a rise of the free glucose concentration. Hers' [8] explanation of the mechanism of Pompe's disease (type II glycogenosis) has provided clear evidence for the necessity of participation of an acidic $\alpha$-glucosidase in the glycogen breakdown. But the role of the neutral enzyme is still unclear despite the fact that it can be found in various tissues and body fluids of several animal species [10].

Alpha-amylase (EC 3.2.1.1), with its ability to hydrolyze the inner bonds of highly polymerised $\alpha$-1,4-glucans, is a widespread enzyme, and in the glycogen storing tissues this enzyme may be engaged in its breakdown [9] by providing a kind of supportive reaction for the mainstream phosphorolytic glycogenolysis.

The relationship between phosphorolytic and hydrolytic pathways of glycogenolysis depends on the cells' state of differentiation. Higher activity of hydrolytic enzymes has been observed in fast dividing cells during early stages of ontogenesis [11]. This fact may suggest that also tumor tissue can use the hydrolytic pathway of glycogen breakdown to produce an additional pool of free glucose, the substrate for hexokinase - an enzyme known to be highly expressed in rapidly growing tumor cells [12]. This additional pool of free glucose may also assist in the Crabtree effect, which is a metabolic feature of tumors in several tissues [6].

In this paper the levels of the mentioned glycogenolytic activities in tissue extracts from brain tumors have been compared, and the problem of glycogenolysis in astrocytoma tumors has been shortly discussed.

\section{MATERIALS AND METHODS}

Ten extracts of human brain tumor cells were used for experiments; 5 were from anaplastic astrocytoma cells and 5 from glioblastoma multiforme. Control extracts were prepared from carefully dissected, morphologically unchanged surrounding tissue, routinely excised with every tumor. A histochemical analysis of the tissue was the basis for classification of particular tumors. Samples of tumor tissue were taken intra operationem at the Department of Neurosurgery, Wrocław Medical Academy. Each group of samples was obtained from 2 male and 3 female patients. Two of the anaplastic astrocytoma tumors were localized in a frontal lobe of cerebral cortex and 3 in a temporal lobe; glioblastoma multiforme tumors were all in the temporal lobe. Samples were obtained with agreement, and in accordance with the rules of the ethics committee. 
Tumor tissue was frozen at $-18^{\circ} \mathrm{C}$ within 15 min after surgery; and enzyme activities were assayed within $48 \mathrm{~h}$. Frozen tissue was disintegrated mechanically in 5 volumes of $\mathrm{NaCl} /$ $\mathrm{P}_{\mathrm{i}}$ buffer in a small Potter homogenizer; then insoluble parts were separated by centrifugation at $5000 \times \mathbf{g}$.

Assay of neutral and acid a-glucosidases. Glucosidase activity was assayed by the method of Dalquist [13], using liver glycogen (Wytwórnia Surowic i Szczepionek, Kraków, Poland) and/or maltose (Merck) as substrates. Incubation was performed in 100 $\mathrm{mM}$ veronal/acetate buffer of $\mathrm{pH} \mathrm{6.6}$; and/or in $100 \mathrm{mM}$ acetate buffer of $\mathrm{pH} 4.5$; which were optimal for the respective hydrolytic activities. Aliquots $(50 \mu \mathrm{l})$ of tissue extracts were diluted to the final volume of $250 \mu \mathrm{l}$. Protein concentration in such a mixture was close to $2 \mathrm{mg} / \mathrm{ml}$. Concentration of glycogen was $1.6 \%(\mathrm{w} / \mathrm{w})$, while that of maltose was $0.5 \%$ $(\mathrm{w} / \mathrm{w})$. Samples were incubated at $37^{\circ} \mathrm{C}$ with glycogen or maltose for $60 \mathrm{~min}$ or $30 \mathrm{~min}$, respectively. Hydrolysis of glycogen was stopped by addition of two volumes of frozen ethanol then the samples were kept at $-18^{\circ} \mathrm{C}$ for 5 to $10 \mathrm{~min}$. Temperature denaturation (2 min boiling) was used to stop the reaction of maltose hydrolysis. Reference samples were obtained by the same treatment, but at zero time of incubation. After centrifugation (5000 $\times g$ ) glucose was determined in supernatants by an enzymatic procedure, using a glucose oxidase/peroxidase mixture ("Analco"). Nanomoles of hydrolysed $\alpha$-1,4-linkages per $1 \mathrm{~min}$ of incubation (milliunits), per $1 \mathrm{~g}$ of a tissue or/and per $1 \mathrm{mg}$ of protein, were calculated.

Assay of $\alpha$-amylase. Crystallised amylose, which is the best natural substrate for $\alpha$-amylase, was used in the assay. A calibration curve, representing the relationship of the product's reducing power versus the iodine complex absorbance of the residual amylose, was used for evaluation of the amount of hydrolyzed $\alpha$-1,4-linkages.
Preparation of the calibration curve. Crystalline human salivary $\alpha$-amylase (approximate concentration $10 \mathrm{mU}$ per $\mathrm{ml}$ ) was incubated with $0.35 \%$ amylose in $100 \mathrm{mM}$ Tris-maleate buffer of $\mathrm{pH} 6.8$ containing 150 $\mathrm{mM} \mathrm{NaCl}$. Progress of the reaction was monitored by two independent procedures:

- Increase of the reducing power was determined by the method of Robyt et al. [14] which is the only procedure giving results not affected by the degree of polymerization of $\alpha$-1,4-glucans.

- Decrease in the blue value of iodine-amylose complex was determined according to Krisman [15]. Monitoring was continued until the absorbance of iodine complex dropped to approximately $25 \%$ of its starting value. The curve, representing the reciprocal relationship between the blue value and the concentration of reducing groups from the newly broken $\alpha$-1,4-linkages was drawn, and served for calculation of $\alpha$-amylase activity in experimental material. A new calibration curve was prepared for each set of solutions used for the assay.

Substrate solution. Thirty five mg aliquots of Koch-Light's amylose, crystallized from butanol and thoroughly dessicated, were dissolved overnight in $100 \mu \mathrm{l}$ of $\mathrm{Me}_{2} \mathrm{SO}$ in glass tubes. Tubes were then placed in the boiling water-bath and hot $100 \mathrm{mM}$ Tris-maleate buffer of $\mathrm{pH} 7.0$ containing $150 \mathrm{mM} \mathrm{NaCl}$, was slowly added with mixing with a glass rod until the very dense amylose- $\mathrm{Me}_{2} \mathrm{SO}$ mixture was completly dissolved. After slow cooling to approximately $40^{\circ} \mathrm{C}$ the final volume was adjusted to $10 \mathrm{ml}$ with the same buffer.

Assay samples. Tissue extract $(50 \mu \mathrm{l})$ was mixed with $450 \mu \mathrm{l}$ of the substrate solution and incubated for $40 \mathrm{~min}$ at $30^{\circ} \mathrm{C}$. The reaction was stopped by adding $4.5 \mathrm{ml}$ of hot buffer, followed by 2 min of boiling.

Reference samples. Tissue extract $(50 \mu \mathrm{l})$ was mixed into $4.5 \mathrm{ml}$ of hot (boiling water bath) buffer and, after 2 min of boiling, $450 \mu \mathrm{l}$ of substrate was added. 
Blank sample. Tissue extract (50 $\mu \mathrm{l})$ was mixed with $4.95 \mathrm{ml}$ of buffer.

Aliquots of assay samples, reference samples and/or blank sample, $200 \mu \mathrm{l}$ each, were mixed with $1.8 \mathrm{ml}$ of fresh iodine reagent [15] (1.3 mg of iodine and $13 \mathrm{mg}$ of potassium iodide in $130 \mathrm{ml}$ of saturated calcium chloride). Absorbance of reference and assay samples was measured against the blank sample at $670 \mathrm{~nm}$. The percentage of lost blue value was calculated, and the equivalent of hydrolysed $\alpha$-1,4-linkages was finally evaluated from the calibration curve.

Results are presented as nanomoles of the reducing groups produced from amylose, per gram of tissue and/or per $1 \mathrm{mg}$ of protein.

Phosphorylase activity was assayed by the synthesis test [16]; and protein concentration was determined according to the Lowry procedure [17]. Results were statistically verified with Student's $t$-test.

\section{RESULTS}

An increase in the $\alpha$-glucosidase activity in anaplastic astrocytoma extracts, assayed with glycogen as a substrate at $\mathrm{pH}$ 6.6, was the most clearly visible change caused by the studied $\alpha$-glucan depolymerizing enzymes (Table 1). An approximately threefold rise of this activity has also been found in glioblastoma multiforme extracts.

The change in $\alpha$-glucosidase activity $(\mathrm{pH}$ 6.6), determined against maltose as a substrate, was lower (Table 1) and statistically significant for the glioblastoma on $\mathrm{mU}$ per 1 $\mathrm{mg}$ of protein basis. For anaplastic astrocytoma, the change was statistically significant only for the results presented on $\mathrm{mU}$ per $1 \mathrm{~g}$ of a sample basis.

Activity of acid $\alpha$-glucosidase (pH 4.6) has also been found elevated in both kinds of tumor extracts (Table 1); but again, only the glycogen hydrolysis results were statistically fully verifiable, while changes in maltose hydrolysis could sustain statistical verification only when presented per mass of the sample rather than per $1 \mathrm{mg}$ of protein (Table 1 ).

The control extracts as well as those from tumor tissue showed higher level of acid glucosidase activity in comparison to the neutral enzyme (Table 1).

Table 1. Activity of “exo" and "endo" $\alpha-1,4$-glucanases and phosphorylase in extracts from brain tumors

\begin{tabular}{lccc}
\hline & \multicolumn{3}{c}{ Kind of tissue } \\
Kind of activity; pH; substrate & Unchanged (control) & $\begin{array}{c}\text { Anaplastic } \\
\text { astrocytoma }\end{array}$ & $\begin{array}{c}\text { Glioblastoma } \\
\text { multiforme }\end{array}$ \\
\cline { 2 - 4 }$\alpha$-1,4-Glucosidase; $\mathrm{pH}$ 6.6; glycogen & $28 \pm 3$ & $107 \pm 11^{*}$ & $95 \pm 13^{*}$ \\
& $(4.2 \pm 1.1)$ & $\left(11.7 \pm 1.9^{*}\right)$ & $\left(10.8 \pm 1.9^{*}\right)$ \\
$\alpha$-1,4-Glucosidase; $\mathrm{pH}$ 6.6; maltose & $209 \pm 35$ & $367 \pm 49^{*}$ & $314 \pm 64$ \\
& $(31.7 \pm 1.9)$ & $(36.2 \pm 3.9)$ & $\left(45.8 \pm 6.0^{*}\right)$ \\
$\alpha$-1,4-Glucosidase; $\mathrm{pH}$ 4.5; glycogen & $75 \pm 8$ & $183 \pm 29^{*}$ & $154 \pm 31^{*}$ \\
& $(11.4 \pm 1.4)$ & $\left(18.0 \pm 3.4^{*}\right)$ & $\left(19.2 \pm 3.4^{*}\right)$ \\
$\alpha$-1,4-Glucosidase; $\mathrm{pH}$ 4.5; maltose & $518 \pm 28$ & $915 \pm 93^{*}$ & $919 \pm 100^{*}$ \\
& $(78.5 \pm 5.5)$ & $(91.6 \pm 8.8)$ & $(91.7 \pm 4.1)$ \\
$\alpha$-Amylase; pH 7.0; amylose & $600 \pm 13$ & $450 \pm 25^{*}$ & $482 \pm 41^{*}$ \\
Phosphorylase without AMP; pH 7.0; Glc-1-P & $(90.5 \pm 3.5)$ & $\left(44.2 \pm 4.6^{*}\right)$ & $\left(51.3 \pm 6.3^{*}\right)$ \\
Phosphorylase with AMP; pH 7.0; Glc-1-P & $78 \pm 14$ & traces & traces \\
\hline
\end{tabular}

The results of particular determinations are presented as milliunits per $1 \mathrm{~g}$ of tissue and (in parentheses) per $1 \mathrm{mg}$ of protein. Values shown are mean \pm S.D.; $\mathrm{n}=5$ for each group. ${ }^{*} P<0.05$ as compared with control. 
An opposite change has been found in the activities of both phosphorylase and $\alpha$-amylase. Phosphorylase activity (assayed by the synthesis test), disappeared almost completely and $\alpha$-amylase activity dropped significantly, in both kinds of tumor cells (Table 1).

\section{DISCUSSION}

Direction and intensity of changes in the activity of both, neutral and acid $\alpha$-glucosidase, and in phosphorylase, support some early findings on the phylogenetic and ontogenetic relationship between the phosphorolytic and hydrolytic pathways of glycogen depolymerization ([11] and references therein). According to this concept, the phosphorolytic pathway of glycogen breakdown developed at later stages of evolution and in more differentiated cells, while the hydrolytic enzymes were engaged in glycogen breakdown at earlier steps of evolution, or in fast dividing cells of earlier stages of differentiation. Such cells are usually better equipped for anaerobic conditions, which seems to be the case in brain tumor tissue, where faster lactate turnover has been found [5]. The threefold increase in the activity of glucose-producing, glycogen-hydrolyzing enzymes in both kinds of the studied tumor cells seems to be in a good agreement with the upward regulation of hexokinase expression by the mutated $\mathrm{p} 53$, found in hepatoma and other fast dividing cells [12]. The concerted increase of $\alpha$-glucosidase and hexokinase activities may have fully replaced the activity of phosphorylase, which has almost completely disappeared from both anaplastic astrocytoma and glioblastoma multiforme tumor extracts.

Since $\alpha$-amylase also belongs to the group of $\alpha$-1,4-glucan hydrolysing enzymes, the decline of its activity in tumor cells does not fit very well to the above mentioned view [11]. But the parallel change in $\alpha$-amylase and phosphorylase activities has already been noticed in muscle tissue [18] and may suggest some co- operation between the "exo" mechanism of phosphorylase, depolymerizing outer branches of glycogen, with the "endo" mechanism of $\alpha$-amylase action, degrading the highly branched core of glycogen molecule. This cooperation could be the factor underlying parallel regulation of those otherwise different enzymes.

\section{R E F E R E N C E S}

1. Mennerick, S. \& Zoromski, C.F. (1994) Nature 368, 59-62.

2. Eyre, J.A., Stuart, A.G., Forsyth, R.J., Heaviside, D. \& Bartlett, K. (1994) Brain Res. 635, 349-352.

3. Dringen, R., Gebchardt, R. \& Hamprecht, B. (1993) Brain Res. 623, 208-214.

4. Liberski, P.P. \& Kordek, R. (1997) Ultrastruct. Pathol. 50. 107-113.

5. Terpstra, M., Gruetter, R., High, W.B., Meschner, M., DelaBarre, L., Merkle, H. \& Garwood, M. (1998) Cancer Res. 58, 5083-5088.

6. Krebs, H.A. (1972) in Essays in Biochemistry (Campbell, P.N. \& Dickens, F., eds.) vol. 8, pp. 1-34, Academic Press, London, New York.

7. Akopian, A.S., Popova, I.A., Promyslov, M.Sh. \& Rosenfeld, E.L. (1976) Voprosy Neirokhirurgii 6, 38-41 (in Russian with English summary).

8. Hers, H.G. (1963) Biochem. J. 86, 11-16.

9. Brosemer, R.W. \& Rutter, W.J. (1961) J. Biol. Chem. 236, 1253-1258.

10. Hibi, N., Chiba, S. \& Shimomura, T. (1976) Agricult. Biol. Chem. 40, 1805-1812.

11. Karpiak, S.E. \& Iwanowski, H. (1965) Arch. Immunol. Ther. Exp. 13, 368-376.

12. Mathupala, S.P., Rempel, A. \& Pedersen, P.L. (1997) J. Biol. Chem. 272, 22776-22780. 
13. Dahlquist, A. (1961) Biochem. J. 80, 547-551.

14. Robyt, J.F., Ackerman, R.J. \& Keng, J.G. (1972) Anal. Biochem. 45, 517-524.

15. Krisman, C.R. (1962) Anal. Biochem. 4, 1723.

16. Huijing, F. (1974) in Clinical Biochemistry Principles and Methods (Curtis, H.Ch. \& Roth,
M., eds.) vol. 2, pp. 1225-1251, Walter de Gruyter, Berlin, New York.

17. Lowry, O.H., Rosebrough, N.J., Farr, A.L. \& Randall, R.J. (1951) J. Biol. Chem. 193, 265-275.

18. Hutny, J. (1968) Zesz. Nauk. WSR Wroclaw. Weterynaria 23, 243-254 (in Polish with English summary). 